\title{
THE PRICE OF MOTIVATING CORPORATE TOP MANAGERS USING WARRANTS
}

\author{
С.Н. Яшин, Ю.В. Трифонов, Е.В. Кошелев \\ ЦЕНА МОТИВАЦИИ ТОП-МЕНЕДЖЕРОВ КОРПОРАЦИИ \\ С ПОМОЩЬЮ ВАРРАНТОВ
}

In today's economic environment, an important characteristic of top-echelon executives includes not only their qualification and business reputation but also their motivation for the company development. The majority of presentday investigators have come to a general consensus thatthe performance of the top management in a company must be objectively evaluated by the market, rather than by the subjective human factor (i.e., by the top managers themselves). While using warrants to evaluate the motivation of the top-managers is undoubtedly appealing, it is evident that this motivation, as any other, must have a certain value for the company, and needs to be pre-evaluated. Even though the due date for new warrants will occur in the far future, the market is even now revaluating corporate securities on the basis of future opportunities. The common-stock value is adjusted with allowance for anticipated dilution that results from exercising warrants. The Black-Scholes model is used in most cases in order to evaluate European options, since it provides a conservative, i.e., the lowest, option value. However, a model with dividends for a European-type warrant should be used for more realistic corporate business presentation. In such a case, the warrant and stock values can be theoretically adjusted until the warrant value has become equal to zero. The stock value, however, will significantly decrease as compared to the original market value. But in actual practice, markets ineffectually respond to issuing warrants by companies; therefore, the stock value declines in a minor way. We then recommend to decide upon the adjustment of the fair stock price which would be following the first specification of the fair warrant price. In this case, the price of motivating top managers using warrants is calculated through multiplying the magnitude of reduction in the stock value by the number of company shares in circulation.

TOP MANAGEMENT MOTIVATION; WARRANTS; BLACK-SCHOLES MODEL; BLACK-SCHOLES MODEL WITH DIVIDENDS.

В современных экономических условиях важной характеристикой управленческого персонала высшего звена являются не только его квалификация и деловая репутация, но также и мотивация на развитие компании. Большинство современных исследователей пришли к общему мнению, согласно которому для объективной оценки деятельности топ-менеджмента компании необходимо, чтобы результаты их работы оценивал рынок, а не субъективный человеческий фактор (в лице тех же топ-менеджеров). При всей привлекательности оценки мотивации топ-менеджеров с помощью варрантов очевидно, что данная мотивация, как и любая другая, должна иметь определенную значимость для компании, которую необходимо предварительно оценить. Несмотря на то, что срок исполнения новых варрантов наступит в отдаленном будущем, рынок уже сейчас переоценивает акции компании, исходя из будущих возможностей. Цена акций корректируется с поправкой на ожидаемое разбавление, которое является следствием исполнения варрантов. Для оценки европейских опционов чаще всего используется модель Блэка-Шоулза, так как она дает консервативную, т. е. наиболее низкую, стоимость опциона. Однако для более реалистичной картины деятельности корпорации следует использовать модель с дивидендами для варранта европейского типа. При этом процесс корректировки стоимостей варранта и акции теоретически можно проводить до тех пор, пока стоимость варранта не станет равной нулю. Стоимость акции при этом уменьшится существенно, по сравнению с первоначальным рыночным значением. Однако на практике рынки слабо реагируют на выпуск варрантов компаниями, таким образом, стоимость акций снижается незначительно. Мы рекомендуем остановиться на той корректировке справедливой цены акции, которая будет наблюдаться после первого уточнения справедливой цены варранта. Цена мотивации топ-менеджеров с помощью варрантов в этом случае вычисляется путем умножения величины снижения стоимости акции на количество акций компании в обращении.

МОТИВАЦИЯ ТОП-МЕНЕДЖЕРОВ; ВАРРАНТЫ; МОДЕЛЬ БЛЭКА-ШОУЛЗА; МОДЕЛЬ БЛЭКА-ШОУЛЗА С ДИВИДЕНДАМИ.

1. Introduction. Under current dynamic conditions of the capital market development in Russia, the company management efficiency becomes more and more relevant. Company owners cannot take fully qualified managerial decisions, which is why they employ top 
managers for whom company management is a profession [1]. Against this background, not only qualification of top-echelon managerial personnel but also its reputation and motivation for the company growth and development are important factors [2]. Conventional compensation packages of a modern corporate top manager used for motivation may comprise the following [3]:

- a salary;

- a bonus conditioned on the company's profitability;

- an initiative part based on price appreciation;

- a right to use corporate assets;

- a social package.

However, this material remuneration system for managers has the following major deficiencies [3]:

- a tenuous relationship between remuneration and real accomplishments;

- an inadequate level and a high disparity between salaries of top managers and employees;

- manipulability of company reporting.

The problem of effectively motivating corporate top managers is the subject of wide speculation in the financial literature. Managers are often more interested in their own well-being than in company prosperity. There arises a conflict of interest, which leads to shareholders incurring agency costs $[4,5]$.

2. Task Description. There is a number of methods and recommendations for motivating top managers more efficiently. For example, in his book [4], Limitovsky showed how the size of a top manager's material remuneration could be correlated to the eventual result of the company's activities under the leadership of such an agent. For that end, it is advised to use not earnings, since they may be manipulated using both accounting and non-accounting techniques, but economic value added (EVA) that is created by new investment or innovative projects of the company. But in this case, if projects are shortterm or medium-term, maximizing the EVA may not result in maximizing the net present value (NPV) of the project [4].

In order to solve the top management motivation discrepancy problem using the EVA method, a number of authors [6, 7] propose to use a modified EVA indicator, i.e. $\operatorname{EVA}(m)$. This makes it possible to encourage top managers only based on the results of already accomplished projects or their significant stages.

However, it is important to motivate top managers not only financially but also nonfinancially. Thus, book [8] obtained results representing a practical utility for reference motivational preferences of top managers. For any innovative project, it is possible to define an optimal value of NPV, relying on which it is fine to organize an efficient motivation system for the top manager who, in this case, becomes a «friend» to the company. If this approach is ignored, the top manager may turn into a «diversionist» or simply fail to find a common language with the company owners and drop out of the project. In this regard, it was established that the equilibrium value of NPV was in direct relationship to the premium fund available in the company. This imposes restrictions on the company motivation capabilities, which is also to be considered.

As can be seen from the above, a more profound look at the issue of effective motivation of corporate top management implies subdividing these agents into corporate friends, regents (absorbing the company capital to the greatest extent possible without any commitment to results) and diversionists (taking decisions to the detriment of other shareholders and the business in general). At the same time, Limitovsky [2] proposes to regard top managers as two types of insiders in a company: insiders adding value to the company and insiders motivated to increase the company's value. In this regard, in practice, an insider's share in the profits is determined according to Limitovsky's model [2]; this share outweighs the loss of alternative profits (diversionist) and at the same time creates no destructive motivation (regent). Consequently, paper [2] proves an important practical conclusion consisting in the fact that a rational insider bearing no pecuniary responsibility for accepting inefficient projects cannot be motivated in a constructive way.

However, many authors believe that for a really objective evaluation of managers, it is required that their work be evaluated by the market, rather than by the managers themselves $[4,9,10]$. Then, alternate ways to resolve the top management motivation conflicts using the EVA or $\operatorname{EVA}(m)$ method may include the following [4].

1. Transferring a portion of the company shares to such managers. In this case, however, the managers become the key dangerous persons in the joint-stock company.

2. Indexing the managers' fees according to the company's stock value. However, transferring, for instance, stock call options to them in that case is dangerous as the managers may become the company's co-owners. That is why it is better 
to use non-deliverable options providing for no delivery of any underlying asset. In addition, options must be European and confined to the project completion time. This is required in order to prevent the managers from any action aimed at a short-term rise in the market stock price.

3. Research Technique. Motivating top managers by means of call options on shares in the company managed by them is fairly popular in the practice of the financial and academic community. Thus, Brigham and Houston [11] write that the manager remuneration system must be arranged in such a way that managers should receive fees according to a stock value in a long-run period, rather than at the time of exercising a share option. This means that share options should be transferred step by step, over a period of several years, so that managers would be interested in maintaining a high stock value all this while.

However, stock call options issued to top managers are essentially different from conventional stock options. They are usually called warrants. In this context, let us consider in detail what a warrant is by definition.

Brigham and Gapensky [12] write that a warrant is an option issued by a company, which entitles its holder to purchase a preset number of shares in the company at a determined price. Warrants are often distributed when placing a loan and are used to induce investors to buy longterm bonds of a company having a lower interest rate than under other purchase conditions.

Marshall and Bansal [13] assert that warrants differ from stock options by several positions. First, warrants are issued by the company whose shares are indeed an asset forming the basis of a warrant. Second, warrants not necessarily cover 100 shares. Third, they have a very extensive validity period, usually from three to ten years. Fourth, they do not have to be exercised throughout the validity period; the exercise period may be more limited. Fifth, they are often issued together with other corporate securities «attached» to them - in most cases, debt securities and preferred shares, but warrants are detachable. Namely, if debt securities or shares have been purchased together with warrants, then the warrants can be «detached» and sold separately from such debt securities or stockholders' equity. Warrants are also used as an incentive for key employees to motivate them to work to the best advantage of shareholders (to reduce agency costs).

Kuznetsov [14] further specifies additional properties of warrants. Unlike call options, warrants are issued in limited quantities. The total quantity of warrants of a certain type decreases in course of time as they are exercised. Exercising warrants results in their gradual reduction, while exercising call options has no impact on the issuing entity's position. Warrants are usually issued for extended lengths of time (for 5 years and longer). Perpetual warrants are issued as well.

In this connection, Hall [9] differentiates such concepts as a «warrant» and a «managerial stock option». In particular, he defines a warrant as a call option that is often associated with issue of bonds. A warrant is issued in addition to bonds in order to make them more attractive to investors. Generally, warrants remain in force for many years. They are sometimes listed separately from bonds, to which they were originally attached. Hall defines a managerial stock option as a call option issued to incentivize corporate managers.

Nevertheless, Damodaran [15] defines a warrant in a simpler way, namely as a call option issued by a company either to perform a contract providing for the management remuneration or to raise the stockholders' equity. We will rely on this definition below.

While motivating top managers through using warrants is fairly attractive, it stands to reason that this motivation, as any other, must have a certain value for a company. Recall that it is impractical to issue American warrants to managers. They should be European. However, while the due date for new warrants will occur in the far future, the market will even now revaluate corporate securities on the basis of these future opportunities. A potential warrant exercise will increase the number of circulating corporate securities and infuse new blood into the company. At the same time, both these factors have an effect on the stock price. The anticipated negative effect (due to «dilution») of the warrant exercise will debase other warrants that are similar to call options. The stock price is also adjusted with allowance for the anticipated dilution that results from the option exercise [15].

Damodaran uses the Black-Scholes model without dividends in his book [15] to valuate a warrant. However, for more realistic corporate business presentation, a model with dividends for a European-type warrant should be used. For example, Krushvits, Shefer and Shvake [17] suggest using a binomial CRR model [18] with dividends. But this model is a single-period model, and dividends are paid out only once at the end of the scheduled period. 
Burenin describes both a binomial multiperiod share option pricing model with permanent dividends and the Black-Scholes model with permanent dividends in his book [19]. The latter model is also used by such authors as Hall [9] and Damodaran [15]. Even though the abovementioned authors use these models for conventional equity options, their application for warrants has some computational peculiarities that we are going to analyze below. It should be also noted that the Black-Scholes model is more often used to valuate European options since it provides a lowest, i.e., conservative, option value [4]. Therefore, to estimate the value of a European warrant, we are going to use the Black-Scholes model with permanent dividends. Then let us describe the proposed model for calculating a top management motivation price using warrants.

4. Model Setup. The adjustment for dilution affecting the stock price is simple enough in the Black-Scholes model. The stock price is adjusted with allowance for the anticipated dilution that results from exercising the option. For warrants, for instance [15]:

$$
S_{k}=\frac{S_{k-1} n_{S}+W_{k-1} n_{W}}{n_{S}+n_{W}},
$$

where $S$ is the current share value (RUB), $n_{S}$ is the number of shares in circulation (pcs), $W$ is the value of a warrant in circulation (RUB), $n_{W}$ is the number of warrants in circulation (pcs), $k$ is the iteration number.

When exercising warrants, the number of circulating shares will increase, which will result in a reduction in the share price. The numerator of the formula shows the stockholders' equity market value, including shares and warrants in circulation. The reduction $S$ will lower the call option value [15].

The longer the option life is, the less practical is the estimated present value of dividends, so an alternative approach can be used. If throughout the option life a permanence of dividend yield is expected $(y=$ dividends/current asset value), then the Black-Scholes model can be modified in the following way $[9,15,19]$ :

$$
\begin{gathered}
W=S e^{-y t} N\left(d_{1}\right)-K e^{-r t} N\left(d_{2}\right) ; \\
d_{1}=\frac{\log \frac{S}{K}+\left(r-y+\frac{\sigma^{2}}{2}\right) t}{\sigma \sqrt{t}} ; \\
d_{2}=d_{1}-\sigma \sqrt{t},
\end{gathered}
$$

where $t$ is the time to the option exercise (years); $N(d)$ is the cumulative normal distribution function; $K$ is the strike price (RUB); $r$ is the continuous yearly rate of risk-free return (growth power) $(\%) ; \sigma$ is the mean-square deviation of the annual price/earnings ratio (\%).

In such an analysis, there is something like an endless circle since for the estimated adjustment for dilution $S$, it is required to know the warrant value $W$, and for valuation of the warrant, it is required to have the adjustment for dilution $S$. This problem can be solved by starting the calculation process with an assumption in terms of the warrant value $W_{0}$ (for example, the current market value of the warrant). This will give us the required value $S_{1}$, and the obtained value can be used as an input parameter for revaluation of the warrant value $W_{1}[15]$.

5. Empirical Results. As an illustration of the model, let us consider the following example [15]. Avatek Corporation is a company dealing with real property. It has 19.637 million circulating shares selling at the price of 0.38 US dollars per share. At the present time, the company has issued for top managers 1.8 million European warrants whose due date expires in 4 years, and whose strike price is 2.25 US dollars. The mean-square deviation of the price/earnings ratio was $93 \%$. The four-year continuous rate for treasury bonds is equal to $4.9 \%$ per annum. The warrants were on sale at the price of 0.12 US dollars per warrant at the time of this analysis. We will also add the condition that the continuous dividend yield will remain unchanged in the next 4 years and will be $2.51 \%$ per annum. It is required to estimate the adjusted share price and warrant value as well as the top management motivation price through the use of the warrants.

Applying the model described by us, we have the following input parameters of the model:

$S_{0}=0.38$ US dollars,

$N_{S}=19.637$ million shares,

$W_{0}=0.12$ US dollars,

$n_{W}=1.8$ million warrants,

$y=2.51 \%, t=4$ years,

$K=2.25$ US dollars,

$r=4.9 \%, \sigma=0.93$.

Then

$$
\begin{gathered}
S_{1}=\frac{S_{0} n_{S}+W_{0} n_{W}}{n_{S}+n_{W}}=\frac{0.38 \cdot 19.637+0.12 \cdot 1.8}{19.637+1.8}= \\
=0.358169 \text { (US dollars). }
\end{gathered}
$$


This adjustment for the dilution of the share price allows to revaluate the fair market value of the warrant $W_{1}$ :

$$
\begin{gathered}
d_{1}=\frac{\log \frac{0.358169}{2.25}+\left(0.049-0.0251+\frac{0.93^{2}}{2}\right) 4}{0.93 \cdot 2}= \\
=-0.006602 ; \\
d_{2}=-0.006602-0.93 \cdot 2=-1.866602 ; \\
N\left(d_{1}\right)=0.5-0.002641=0.497359 ; \\
N\left(d_{2}\right)=0.5-0.469062=0.030938 ; \\
W_{1}=0.358169 e^{-0.0251 \cdot 4} \cdot 0.497359-2.25 e^{-0.049 \cdot 4} \times \\
\times 0.030938=0.103901 \text { (US dollars). }
\end{gathered}
$$

Please note that the obtained values $d_{1}$ and $d_{2}$ do not match the exact tabular values of the cumulative normal distribution function $N(d)$ [4, 12]. That is why, to obtain the exact values, we used the method of proportional parts $[5,17,20]$.

However, our $1^{\text {st }}$ iteration of the values $S$ and $W$ necessitates their further specification. Repeating the above procedure, we obtain the following values $S$ and $W$ in Tab. 1 .
In order to visualize the obtained data, let us construct graphs of the values $S$ and $W$ according to the iteration number (Fig. 1, 2) using the Matlab package for that end [21, 22].

As is clear from the graphs, the values $S$ and $W$ can be theoretically adjusted until the warrant value $W$ has become equal to zero. The stock value $S$, however, will significantly decrease as compared to the original value $S_{0}=0.38$ US dollars. But in actual practice, markets ineffectually respond to issuing warrants by companies; therefore, the stock value declines in a minor way. That is why recommend to decide upon an adjustment of the fair stock price which would be following the first specification of the fair warrant price. In such a manner, the new market price per share will be approximately $S_{2}=0.336819$ US dollars, and the new market price per warrant will be $W_{1}=0.103901$ US dollars. Considering the fact that Avatek Corporation has 19.637 million shares in circulation at the present moment, the top management motivation price estimated through the use of warrants will be approximately $(0.38-$ $0.336819) 19.637=0.847945$ million US dollars.

Table 1

Results of Five Iterations of the Share Fair Market Value $S$ and the Warrant Value $\boldsymbol{W}$ (US dollars)

\begin{tabular}{|l|c|c|c|c|c|}
\hline & Iteration 1 & Iteration 2 & Iteration 3 & Iteration 4 & Iteration 5 \\
\hline Share value $S$ & 0.358169 & 0.336819 & 0.316461 & 0.297072 & 0.27863 \\
\hline Warrant value $W$ & 0.103901 & 0.094364 & 0.085551 & 0.077439 & - \\
\hline
\end{tabular}

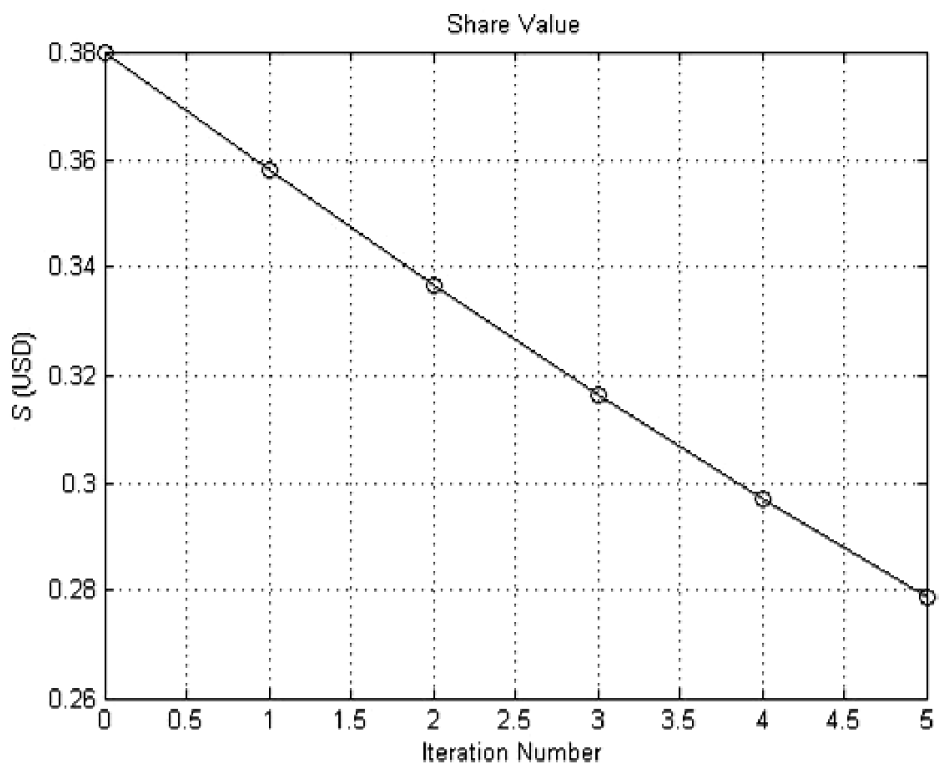

Fig. 1. Share Fair Market Values $S$ According to Iteration Number (US dollars) 


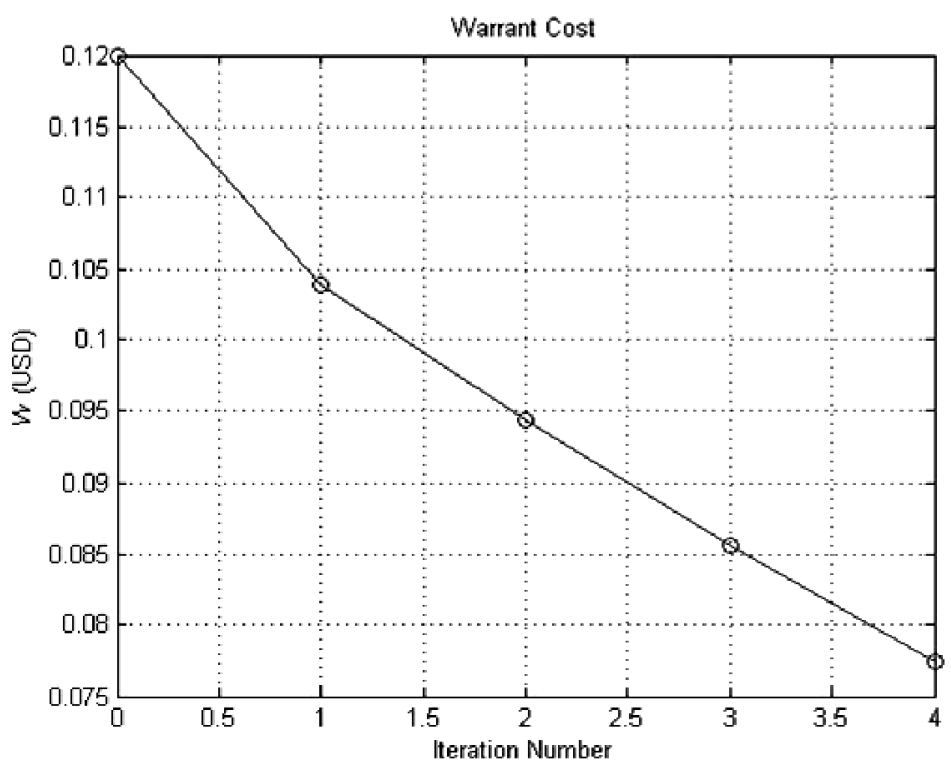

Fig. 2. Warrant Fair Market Values $W$ According to Iteration Number (US dollars)

6. Discussion. This outcome should be compared with the closest equivalent. It would be improvident to consider the obtained motivation price as an absolute indicator that decreases or increases opportunities for the company to invest in new promising projects. Even though the budget of the company's investment fund is highly restricted, this amount of 0.847945 million US dollars is not related directly to the current budget of the company. This indicator is, on the contrary, marketoriented to a greater extent and by no means requires any incentive payment for the work of top managers in such an amount. Quite the opposite, it reflects a current estimate of their performance in accordance with their skill, reputation and motivation level.

We are of the opinion that it makes most sense to compare the amount of 0.847945 million US dollars with the current value of the company's market value growth for the planned period of 4 years. If it is expected that the current growth value exceeds 0.847945 million US dollars, then the method of evaluating the top-managers' motivation through the use of warrants is feasible. However, the forecast accuracy of itself, if only for 4 years ahead, must be performed by highly skilled analysts (as the same goes for absolute adequacy of the motivation value obtained by us and amounting to 0.847945 million US dollars).
7. Conclusion. It is possible to summarize the results of the research conducted in this article by formulating the following practical conclusions.

1. In today's economic environment, an important characteristic of top-echelon executives includes not only their qualification and business reputation but also their motivation for the company's development.

2. The majority of present-day investigators have come to a general consensus that for an objective evaluation of the top management's performance in a company, it is imperative for the results of this performance to be evaluated by the market, rather than by the subjective human factor (which is to say, by the top managers themselves).

3. Indexing managers' fees according to the company's stock value may be accomplished, for instance, by means of providing them with call options on shares. However, such a policy is dangerous since the managers are permitted to become the company's co-owners. That is why we advise to use non-deliverable options providing for no delivery of any underlying asset. In addition, options must be of the European type and confined to the project completion time. This will help avoid the managers' actions aimed at artificial overestimation of the results of their work, for instance, a short-term rise in the market price of shares in the company managed by them. 
4. Motivating top managers by means of call options on shares in the company managed by them is fairly popular in the practice of the financial and academic community. However, stock call options issued to top managers are essentially different from conventional stock options. They are usually called warrants.

5. Even though evaluating top-managers' motivation through the use of warrants is certainly attractive, it stands to reason that this motivation, as any other, must have a certain value for the company. While the due date for new warrants will occur in the far future, the market is even now revaluating corporate securities on the basis of future opportunities. The common-stock value is adjusted with allowance for anticipated dilution that results from warrant exercise.

6. The Black-Scholes model is used in most cases in order to valuate European options, since it provides a conservative, i.e., lowest, option value. However, for more realistic corporate business presentation, a model with dividends for a European-type warrant should be used.

7. A methodological difficulty of this analysis is in the existence of a kind of an endless circle since for an estimated adjustment for any stock value dilution, it is required to know the warrant value, and for valuation of the warrant, it is again required to have an adjustment for the stock value dilution. This problem can be solved by starting the calculation process with an assumption in terms of the warrant value (for example, by taking the current market value of the warrant). This will provide an initial estimate of the stock value that can be then used as an input parameter for revaluation of the warrant value.

8. The stock and warrant values can be theoretically adjusted until the warrant value has become equal to zero. The stock value, however, will significantly decrease as compared to the original market value. But in practice, markets ineffectually respond to companies issuing warrants. Therefore, the stock value only decreases insignificantly. That is why it is recommended for practitioners to decide upon the adjustment of the fair stock price which would be following the first specification of the fair warrant price. In this case, the price of motivating top managers using warrants is calculated through multiplying the magnitude of reduction in the stock value by the number of the company shares in circulation.

9. The obtained top management motivation price should be compared with the current value of the company's market value growth for the planned period until the warrants are exercised. If it is expected that the current growth value exceeds the top management motivation price, then this method of motivation through the use of warrants is feasible.

The results obtained in this article may be useful to company owners and financial analysts. They help more efficiently motivate salaried corporate top managers comparing the price of their motivation with the predicted growth of the company business market value.

This article has been prepared with financial support from the Russian Foundation for Humanities. Grant No. 15-02-00102.

\section{REFERENCES}

1. Porter M.E. On competition. Boston, Harvard Business School Press, 1998. 485 p.

2. Limitovsky M.A. Reputation, qualification and motivation as value drivers. Russian Management Journal, 2009, no. 7(2), pp. 51-68. (rus)

3. Limitovsky M.A., Lobanova E.N., Minasyan V.B., Palamarchuk V.P. Corporate financial management: teaching and practical aid. Moscow, Urait, 2012. 990 p. (rus)

4. Limitovskiy M.A. Investment projects and real options in emerging markets: teaching and practical aid. 4th ed. Moscow, Urait, 2008. 464 p. (rus)

5. Yashin S.N., Tukkel I.L., Koshelev E.V., Zakharova Yu.V. Economics and financial support of innovative activities: textbook. In 2 vol. Vol. 2: financial support. Nizhni Novgorod, Lobachevsky University, 2016. 709 p. (rus)

6. Limitovsky M.A. Investment projects and real options in emerging markets: teaching and practical aid. Moscow, Delo, 2004. 527 p. (rus)

7. Roche J. The value of nothing: mastering business valuations. London, LES50NS (PUBLISHING) Limited, 2005. 236 p.

8. Yashin S.N., Koshelev E.V., Kuptsov A.V., Podshibyakin D.V. Investment planning of equipment upgrading in a manufacturing company: monograph. Nizhni Novgorod, RADONEZH Printing Shop LLC, 2015. 201 p. (rus)

9. Hull J.C. Options, futures and other derivatives. 
Upper Saddle River. 6th ed. New Jersey, Pearson Prentice Hall, 2006. 814 p.

10. Fisher A., Heinkel R. Reputation and managerial truth-telling as self-insurance. Journal of Economics \& Management Strategy, 2008, no. 17(2), pp. 489-540.

11. Brigham E.F., Houston J.F. Fundamentals of financial management. 12th ed. Mason, SouthWestern Cengage Learning, 2009. 755 p.

12. Brigham E.F., Gapenski L.C. Intermediate Financial Management. 4th ed. Orlando, FL, The Dryden Press, 1993. 1122 p.

13. Marshall J.F., Bansal V.K. Financial engineering: a complete guide to financial innovation. New York, Allyn \& Bacon, Inc., 1992. 728 p.

14. Kuznetsov B.T. Investments. Moscow, YunitiDana, 2006. 622 p. (rus)

15. Damodaran A. Investment valuation: tools and techniques for determining the value of any asset. New York, John Wiley \& Sons, Inc., 2002. 993 p.
16. Black F., Scholes M. The pricing of options and corporate liabilities. Journ. polit. econ., 1973, no. May-June 1973, pp. 637-657.

17. Schafer D., Kruschwitz L., Schwake M. Studienbuch finanzierung und investition. Munchen, Wien, R. Oldenbourg Verlag, 1998. 310 p.

18. Cox J., Ross S., Rubinstein M. Option pricing: a simplified approach. Journal of financial economics, 1979 , no. 7 , pp. 229-263.

19. Burenin A.N. Forwards, futures, options, adventive and yearly derivatives. Moscow, Scientific and Technical Society n.a. Academician S.I. Vavilov, 2005. 540 p. (rus)

20. Chetyrkin E.M. Financial mathematics: textbook 10th ed. Moscow, Delo, 2011. 392 p. (rus)

21. Anufriev I.E., Smirnov A.B., Smirnova E.N. MATLAB 7. St. Petersburg, BHV-Petersburg, 2005. 1104 p. (rus)

22. Polovko A.M., Butusov P.N. MATLAB for a student. St. Petersburg, BHV-Petersburg, 2005. 320 p. (rus)

\section{СПИСОК ЛИТЕРАТУРЫ}

1. Портер М.Э. Конкуренция. М.: Изд. дом «Вильямс», 2005.

2. Лимитовский М.А. Репутация, квалификация и мотивация как драйверы ценности // Российский журнал менеджмента. 2009. Т. 7. № 2. С. 51-68.

3. Лимитовский М.А., Лобанова Е.Н., Минасян В.Б., Паламарчук В.П. Корпоративный финансовый менеджмент: учеб.-практ. пособие. М.: Юрайт, 2012.

4. Лимитовский М.А. Инвестиционные проекты и реальные опционы на развивающихся рынках: учеб.-практ. пособие. 4-е изд., перераб. и доп. М.: Юрайт, 2008.

5. Яшин С.Н., Туккель И.Л., Кошелев Е.В., Захарова Ю.В. Экономика и финансовое обеспечение инновационной деятельности: учебник. В 2 т. Т. 2: Финансовое обеспечение. Н. Новгород: Издво ННГУ им. Н.И. Лобачевского, 2016.

6. Лимитовский М.А. Инвестиционные проекты и реальные опционы на развивающихся рынках: учеб.-практ. пособие. М.: Дело, 2004.

7. Рош Дж. Стоимость компании: от желаемого к действительному. Минск: Гревцов Паблишер, 2008.

8. Яшин С.Н., Кошелев Е.В., Купцов А.В., Подшибякин Д.В. Инвестиционное планирование модернизации оборудования производственной компании: моногр. Н. Новгород: Печатная Мастерская РАДОНЕЖ, 2015.

9. Халл Дж.К. Опционы, фьючерсы и другие производные финансовые инструменты. 6-е изд. М.: Изд. дом «Вильямс», 2007.

10. Fisher A., Heinkel R. Reputation and managerial truth-telling as self-insurance // Journal of economics \& management strategy, 2008, vol. 17, is. 2, pp. 489-540.

11. Бригхэм Ю., Хьюстон Дж. Финансовый менеджмент. 7-е изд. СПб.: Питер, 2013.

12. Бригхем Ю., Гапенски Л. Финансовый менеджмент: Полный курс: В 2 т. СПб.: Экон. школа, 2005.

13. Маршалл Дж.Ф., Бансал В.К. Финансовая инженерия: Полное руководство по финансовым нововведениям. М.: Инфра-М, 1998.

14. Кузнецов Б.Т. Инвестиции. М.: ЮнитиДана, 2006.

15. Дамодаран А. Инвестиционная оценка. Инструменты и техника оценки любых активов. М.: Альпина Бизнес Букс, 2004.

16. Black F., Scholes M. The pricing of options and corporate liabilities // Journ. polit. econ., 1973, May-June 1973, pp. 637-657.

17. Крушвиц Л., Шефер Д., Шваке М. Финансирование и инвестиции: сб. задач и решений. СПб.: Питер, 2001.

18. Cox J., Ross S., Rubinstein M. Option pricing: a simplified approach // Journal of financial economics, 1979, no. 7, pp. 229-263.

19. Буренин А.Н. Форварды, фьючерсы, опционы, экзотические и погодные производные. М.: Науч.-техн. общ-во им. акад. С.И. Вавилова, 2005.

20. Четыркин Е.М. Финансовая математика: учебник. 10-е изд. М.: Дело, 2011.

21. Ануфриев И.Е., Смирнов А.Б., Смирнова Е.Н. MATLAB 7. СПб.: БХВ-Петербург, 2005.

22. Половко А.М., Бутусов П.Н. MATLAB для студента. СПб.: БХВ-Петербург, 2005. 
YASHIN Sergei N. - Lobachevsky State University of Nizhni Novgorod.

603950. Gagarin av. 23. Nizhny Novgorod. Russia. E-mail: jashinsn@yandex.ru

ЯШИН Сергей Николаевич - профессор, заведующий кафедрой «Менеджмент и государственное управление» Нижегородского государственного университета им. Н.И. Лобачевского, доктор экономических наук.

603950, пр. Гагарина, д. 23, г. Нижний Новгород, Россия. E-mail: jashinsn@yandex.ru

TRIFONOV Yurii V. - Lobachevsky State University of Nizhni Novgorod.

603950. Gagarin av. 23. Nizhny Novgorod. Russia. E-mail: trifonovyu052@gmail.com

ТРИФОНОВ Юрий Васильевич - профессор, заведующий кафедрой «Информационные технологии и инструментальные методы в экономике» Нижегородского государственного университета им. Н.И. Лобачевского, доктор экономических наук.

603950, пр. Гагарина, д. 23, г. Нижний Новгород, Россия. E-mail: trifonovyu052@gmail.com

KOSHELEV Egor V. - Lobachevsky State University of Nizhni Novgorod.

603950. Gagarin av. 23. Nizhny Novgorod. Russia. E-mail: ekoshelev@yandex.ru

КОШЕЛЕВ Егор Викторович - доцент Нижегородского государственного университета им. Н.И. Лобачевского, кандидат экономических наук.

603950, пр. Гагарина, д. 23, г. Нижний Новгород, Россия. E-mail: ekoshelev@yandex.ru 